\title{
Reassessing the status of antiphospholipid syndrome in systemic lupus erythematosus
}

\author{
João L Vianna, Hans J Haga, Poonam Tripathi, Ricard Cervera, Munther A Khámashta, \\ G R V Hughes
}

\begin{abstract}
The antiphospholipid syndrome was initially described in 1986. To reassess the validity of antiphospholipid antibodies in systemic lupus erythematosus (SLE), 95 patients with SLE were studied. Their antiphospholipid antibody profile was analysed and correlated with clinical findings such as thrombosis, abortions, or thrombocytopenia. A low prevalence of these antibodies was found (13 patients; $14 \%)$ with a high specificity for thrombosis (92\%) and abortions (92\%).
\end{abstract}

The importance of anticardiolipin antibodies as a risk factor for thrombosis or abortions, or both, in patients with SLE is reaffirmed by this work.

Work carried out over the past few years has led to the definition of the antiphospholipid syndrome as the association of thrombosis, recurrent abortion, and thrombocytopenia with anticardiolipin antibodies and/or the detection of lupus anticoagulant activity in the patient's plasma. $^{1}$

Initial work on this subject showed a high incidence (36-60\%) of anticardiolipin antibodies in patients with systemic lupus erythematosus (SLE) and confirmed the association of the clinical and laboratory findings defined in the antiphospholipid syndrome. ${ }^{2-9}$

To assess the validity of the definition more than five years after the initial description of this syndrome, we decided to study our own population of patients with SLE and to determine the prevalence of anticardiolipin antibodies and their correlation with thrombosis, abortions, and thrombocytopenia.

\section{Patients and methods}

Ninety five consecutive patients with SLE attending the lupus outpatients clinic at $\mathrm{St}$ Thomas's Hospital, London during a six month period were included in this study.

All patients fulfilled four or more of the American Rheumatism Association classification criteria for SLE. ${ }^{10}$ At the time of their consultation, serum samples were collected for laboratory analysis and relevant past clinical and laboratory data were obtained.

Ninety two of the patients were women and three were men, with a mean age of 38.6 (range 17-66) years. The anticardiolipin antibodies were determined in this laboratory by an enzyme linked immunoabsorbent assay (ELISA) as described previously. ${ }^{11}$ The results were expressed as GPL units (immunoglobulin G (IgG)) and MPL units (IgM) and classified as negative, low, moderate, or high positive according to the recommendations of the 1987 workshop on standardisation of the test for anticardiolipin antibodies. ${ }^{12}$

The results were compared with those of serum samples obtained from 95 normal blood donors matched for sex and age.

The conventional Fisher's exact test was used to determine the statistical significance of the clinical and laboratory findings. The sensitivity and specificity of the anticardiolipin antibodies for thrombosis and abortions were determined according to the method of Galen and Gambino. ${ }^{13}$

\section{Results}

Of the 95 patients, $13(14 \%)$, were positive for anticardiolipin antibodies, all 13 being positive for IgG and two also for IgM. No positive results were found among the control subjects $(p<0.005)$. Eight of the 13 patients with positive anticardiolipin antibody results $(62 \%)$ fulfilled the criteria of the antiphospholipid syndrome, six patients having had thrombosis and abortions and two having had either thrombosis or abortions. Six patients had moderate or high levels of IgG anticardiolipin antibodies (figure).

Eighteen patients (19\%) had a past history of venous or arterial thrombosis. The presence of these events was significantly higher among

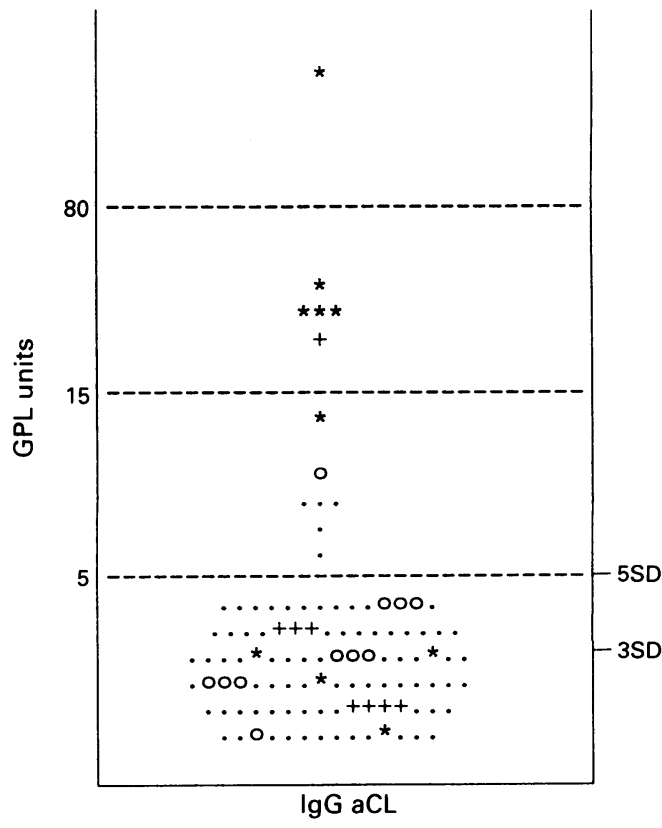

Levels of anticardiolipin antibodies ( $a C L$ ) and clinical manifestations of antiphospholipid syndrome in patients with $S L E . \bigcirc=$ Patients with abortions; $+=$ patients with thrombosis; $*=$ patients with abortions and thrombosis; and $\cdot=$ nothrombosisnor abortions 
patients with anticardiolipin antibodies (7/13; $53 \%)$ than among those without $(11 / 82 ; 13 \%)$ $(\mathrm{p}<0.005)$. When we tested the sensitivity of anticardiolipin antibodies for thrombosis, we found that of the 18 patients with thrombosis, seven had anticardiolipin antibodies (sensitivity $39 \%$ ). In addition, when we tested the specificity, we found that of the remaining 77 patients without thrombosis, 71 had no anticardiolipin antibodies (specificity $92 \%$ ).

Twenty one patients $(22 \%)$ had had recurrent abortions. The incidence of these events was also significantly higher among patients with anticardiolipin antibodies $(7 / 13 ; 54 \%)$ than among those without $(14 / 80 ; 18 \%)(p<0.01)$. When we tested the sensitivity of anticardiolipin antibodies for recurrent abortions, we found that of the 21 patients who had had abortions, seven had anticardiolipin antibodies (sensitivity $33 \%)$. In addition, when we tested the specificity, we found that of the remaining 72 patients without recurrent abortions, 68 had no anticardiolipin antibodies (specificity 92\%).

Twelve patients (13\%) had thrombocytopenia, but no association with the presence of anticardiolipin antibodies was found.

\section{Discussion}

In this series of patients, levels of IgG anticardiolipin antibodies were strongly associated with thrombosis and abortions. This reinforces previous findings stressing such an association. ${ }^{4}$

Although the time between the events and the determinations of the anticardiolipin antibody titres was variable in our study, the finding of this association is of great importance. As noted by Harris, patients with IgG anticardiolipin antibodies who have had thrombosis or abortions are at a higher risk for developing such clinical events in the future. ${ }^{14} 15$ On the other hand, the IgM isotype seems to be less specific for the antiphospholipid syndrome.

The overall prevalence of anticardiolipin antibodies was only $14 \%$. The reported prevalence of anticardiolipin antibodies in patients with SLE has varied widely. ${ }^{16}$ This variability is almost certainly due to the cut off positive level and to patient selection. In this ELISA only values exceeding five GPL or $3.2 \mathrm{MPL}$ units were considered positive. This corresponds to five standard deviations (SD) above that of the normal population. In a large number of published reports, results of two SD above normal are considered positive. In early studies carried out in our laboratory a prevalence of $61 \%$ was found using a cut off for positivity of 2.97 SD. ${ }^{2}$ Thus the rigidity of our standardised ELISA for anticardiolipin antibodies might explain in part the low incidence of anticardiolipin antibodies in this group of patients. Another factor that might have influenced our results is that all patients were receiving some treatment by the time their blood was collected for analysis. ${ }^{17}$

As a result of the association of thrombocytopenia with increased levels of anticardiolipin antibodies in some patients with SLE, ${ }^{18}$ it has been suggested that these antibodies may immunologically alter the platelets, rendering them suitable targets for destruction. ${ }^{19}$ However, Haga et al, using a flow cytometry technique, have failed to show a significant specific binding of affinity purified IgG anticardiolipin antibodies to resting or thrombin activated platelets. ${ }^{20}$ In this study, confirming the results obtained by others, ${ }^{21} 22$ no significant correlation was found between the levels of anticardiolipin antibodies and platelet counts.

Although the mechanism of action of antiphospholipid antibodies is still unclear, the presence of these antibodies should be considered a risk factor for thrombosis and abortions in patients with SLE.

The work of JLV was supported by a grant from CNPq-Conselho Nacional de Desenvolvimento Cientifico e Tecnologico, Brazil.

1 Hughes G R V, Harris E N, Gharavi A E. The anticardiolipin syndrome. F Rheumatol 1986; 13: 486-9.

2 Harris E N, Gharavi A E, Boey M L, et al. Anticardiolipin antibodies. Detection by radioimmunoassay and association with thrombosis in systemic lupus erythematosus. Lancet 1983; ii: 1211-3.

3 Koike T, Sueishi M, Funaki H, Tomioka H, Yoshida S Antiphospholipid antibodies and biological false positive serological tests for syphilis in patients with systemic lupus erythematosus. Clin Exp Immunol 1984; 56: 193-9.

4 Harris E N, Chan J K, Asherson R A, Aber V, Gharavi A E Hughes G R V. Thrombosis, recurrent fetal loss and thrombocytopenia. Predictive value of the anticardiolipin test. Arch Intern Med 1986; 146: 2153-6.

5 Tincani A, Meroni P L, Brucato A, et al. Antiphospholipid and anti-mitochondrial type $M 5$ antibodies in systemic lupus erythematosus. Clin Exp Rheumatol 1985; 3: 321-6.

6 Manoussakis M N, Gharavi A E, Drosos A A, Kitridou R C Moutsopoulos H M. Anticardiolipin antibodies in unselected autoimmune rheumatic disease patients. Clin Immunol Immunopathol 1987; 44: 297-307.

7 Sturfelt G, Nived O, Norsberg R, Thorstensson R, Crook K. Anticardiolipin antibodies in patients with sytemic lupus Anticardiolipin antibodies in patients with syt
erythematosus. Arthritis Rheum 1987; 30: 382-8.

8 Petri M, Golbus M, Anderson R, Whiting-O'Keefe $O$ Corash L, Hellmann $D$. Antinuclear antibody, lupus anticoagulant, and anticardiolipin antibody in women with coagulant, and anticardiolipin antibody in women with idiopat $601-6$.

9 Cervera R, Font J, López-Soto A, et al. Isotype distribution of anticardiolipin antibodies in systemic lupus erythematosus: prospective analysis of a series of 100 patients. Ann Rheum Dis 1990; 49: 109-13.

10 Tan E M, Cohen A S, Fries J, et al. The 1982 revised criteria for classification of systemic lupus erythematosus. Arthritis Rheum 1982; 25: 1271-2.

11 Gharavi A E, Harris E N, Asherson R A, Hughes G R V. Anticardiolipin antibodies. Isotype distribution and phospholipid specificity. Ann Rheum Dis 1987; 46: 1-6.

12 Harris E N, Gharavi A E, Patel S P, Hughes G R V. Evaluation of the anti-cardiolipin antibody test: report of an interof the anti-cardiolipin antibody test: report of an inter1987; 69: 215-22.

13 Galen R S, Gambino R S. Beyond normality: the predictive value and efficiency of medical diagnosis. New York: Wiley, 1975.

14 Harris E N. A reassessment of the antiphospholipid syndrome. f Rheumatol 1990; 17: 733-5.

15 Harris EN. Syndrome of the Black Swan. Brf Rheumatol 1987; 26: $324-6$.

16 Love P E, Santoro S A. Antiphospholipid antibodies. Anticardiolipin and the lupus anticoagulant in systemic lupus erythematosus (SLE) and in non-SLE disorders. Prevalence and clinical significance. Ann Intern Med 1990; 112: 682-98.

17 Alarcón-Segovia D, Delezé M, Oria C V, et al. Antiphospholipid syndrome in systemic lupus erythematosus. A prospective analysis of 500 consecutive patients. Medicine (Baltimore) 1990; 68: 353-65.

18 Harris EN, Asherson R A, Gharavi A E, Morgan S H, Derue G, Hughes G R V. Thrombocytopenia in SLE and related autoimmune disorders: association with anticardiolipin antibody. Brf Haematol 1985; 59: 227-30.

19 Khamashta M A, Harris E N, Gharavi A E, et al. Immune mediated mechanism for thrombosis: antiphospholipid antibody binding to platelet membranes. Ann Rheum Dis 1988; 47: 849-54

20 Haga H J, Christopolous C, Machin S J, Khamashta M A Hughes G R V. Lack of association of anticardiolipin antibodies to platelets demonstrated by flow-cytometry. $\mathrm{Br} \mathfrak{f}$ Rheumatol 1990; 29 (suppl 2): 109.

21 Derksen R H W M, Hasselaar P, Blokziil L, Gmelig Meyling F H J, de Groot P G. Coagulation screen is more specific than the anticardiolipin antibody ELISA in defining a thrombotic subset of lupus patients. Ann R heum Dis 1988; 47: 364-71.

22 Sturfelt G, Nived O, Norberg R, Thorstensson R, Krook K. Anticardiolipin , Norberg R, Thorstensson R, Krook K. erythematosus. Arthritis Rheum 1987; 30: 382-8. 